\title{
Towards Inclusion through lessons from Informal Money Lenders
}

\author{
Yuchun Sui* \\ School of Business management, Tonghua Normal University \\ Tonghua, China \\ E-mail:*dbcy9999@163.com
}

\begin{abstract}
This study analyzes differences in the shadow price of working capital between shrimp farmers who rely on formal credit for all their working capital needs and farmers who also borrow informally. The sample is small, and the results may not be representative of the overall formal and informal markets for small- scale credit schemes. However, some of the results of the study deserve some attention.
\end{abstract}

Keywords-Informal Money; integration; informal credit; Shadow prices

\section{INTRODUCTION}

For this paper, we studied credit markets for smallholder shrimp farmers in Bangladesh. Specfically, we studied whether the increasingly popular small- scale formal credits microcredits - are reaching those who are most likely to use the borrowed funds successfully. Our findings suggest that this may not be the case. We compared farmers who only borrowed formally with those who also used informal loans, and found that, on average, when people only borrowed formally, it was because they were worse credit risks and were shut off from informal loans, rather than because the formal loans were sufficient to cover their credit needs [1-3].

It has long been noted that limited access to credit is an important constraint on rural development in many developing countries, and that there are information problems, selection problems, and other problems inherent in the credit allocation process (Hoff and Stiglitz, 1993; Hermes and Lensink, 2007). The outcome of these problems, discussed in detail in the next section, is frequently that larger farmers have access to cheap formal credit, whereas smaller farmers are forced to resort to costly informal loans. Because of these problems, many attempts at providing cheap credit to smallholder farmers have failed in the past.

One solution that has gained popularity is the use of socalled microcredit financing, where various innovative means such as peer monitoring are used to secure loans. The most well- known microcredit organisation [4-7], the Grameen Bank in Bangladesh, was awarded the Nobel Peace Prize for 2006 jointly with its founder, Muhammad Yunus. Grameen Bank has been in operation since the 1970s. It started in Bangladesh and spread to several other Asian countries, inspiring similar schemes in many developing countries as well. Microcredit schemes have also had a considerable impact on the international development debate. Thus, the United Nations declared 2005 the 'International Year of Microcredit', giving some indication of how important this issue has been considered to be for development in recent years.

We selected the shrimp industry as it is emblematic of the challenges facing micro-credit when applied to high- value agricultural production by smallholders in rural areas of developing nations, and so is a relevant case study selection.

We studied the selection of borrowers by formal microcredit schemes in comparison with traditional informal credit sources in a rural shrimp farming district in Bangladesh. We estimated the shadow prices that farmers are willing to pay for additional credit, an approach that has not previously been used to compare these two forms of credit. Our results indicate that the borrowers who only take formal loans have higher shadow prices for additional credit, and are perceived as worse credit risks than the farmers who also borrow informally. This suggests that the farmers who only borrow formally are a worse group of borrowers, on average, than are the informal borrowers.

We estimate shadow prices for farmers' willingness to pay for additional credit as working capital owing to the lack of appropriate market values. Shadow prices are typically used where either the market price does not reflect the actual value of a good or there is no market price for that good. Shadow pricing is a proxy value of that good, often defined by what an individual must surrender to gain an extra unit of the good.

\section{FORMAL AND INFORMAL CREDIT}

Historically, the lack of access to credit has been an important constraint to rural development in developing countries (OECD, 2016). Microfinance is not the first attempt to address this problem: many developing countries provided cheap, small-scale credit to smallholder farmers in the 1970s. However, these government- run credit schemes were rarely financially viable, and when governments were forced to reduce subsidies in the 1980 s, many rural credit schemes collapsed (Chavas, 2001; Dethier and Effenberger, 2012).

To some extent, the problems that such government credit schemes encountered were not surprising. There are a number of reasons why credit markets tend to be more problematic than many other markets, especially in developing countries, and policy interventions that do not take this into account are likely to fail. The main reason why credit markets are more 
problematic than others is that lenders and borrowers have different information about the quality of the borrower' $s$ project, both with respect to the expected outcome and with respect to the variance of the outcome. Lenders face an adverse selection problem. They can discourage borrowers who have projects with low expected returns by charging high interest rates. However, the borrowers most likely to accept loans with high interest rates are the ones whose projects have high risk but also potentially high returns - for the borrower, that is. This means a higher interest rate will increase the share of risky projects in the lender' s loan portfolio and will, at sufficiently high interest rates, reduce the overall return on the loan portfolio (Akerlof, 1970; Stiglitz and Weiss, 1981). Therefore, lenders will normally try to ration credit through other means as well, especially in settings - such as those in many developing countries - where the scope for collecting debt from defaulters is limited, due to weak institutions.

An important alternative way of rationing credit is that lenders can pose high collateral requirements in order to ensure that borrowers will be able to repay loans even if their projects fail. However, high collateral requirements will, of course, tend to make it difficult for smallholders to borrow. Alternatively, lenders can rely on screening procedures by collecting information in order to identify those borrowers who are likely to succeed. However, such information- gathering is costly for a bank, and the cost will have to be recouped through increasing the cost of the loan. Since the cost of gathering information is likely to be high, even for the small loans that smallholder farmers might be interested in, the costs of such loans become prohibitively high for smaller- scale farmers.

On the other hand, informal lenders who pursue lending as a side activity, and who are based within the communities where they lend, can observe individual farmers' production activities and can more easily identify those who are likely to succeed in their projects. Therefore, such informal lenders have a natural advantage over formal banks. Furthermore, since they have a far smaller adverse selection problem than do the formal banks, and frequently face little competition, they can charge high interest rates on the loans that they provide. Thus, informal credit is characterised by considerably higher interest rates than those seen in formal credit markets, but repayment rates are comparable to or better than those for formal credit.

Attempts to provide cheap credit to farmers through government credit schemes might, in theory, avoid some of the problems facing other formal lenders since it is easier for the government than for private lenders to, for example, confiscate land from farmers who do not repay their loans; in practice, however, these advantages have rarely been used. Governments have been reluctant to enforce loan repayments from defaulting farmers. This, in turn, has meant that government credit schemes have needed subsidies in order to function, and since default rates have frequently increased over time - when other farmers observe that defaulters have not been penalised - most schemes have collapsed at some point (Adams and von Pischke, 1992; Braverman and Guasch, 1993; Armendáriz and Morduch, 2005).
Formal microcredit schemes are an attempt to use social pressure to encourage borrowers to repay their loans. A common setup has been that a group of borrowers in the same village or region are made jointly responsible for each other' $\mathrm{s}$ projects. This moves part of the cost of defaults from the bank to the borrowers. It also reduces the need for screening loan applicants, because neighbours will monitor each other' s loan performance and there will be considerable social pressure on individual borrowers to repay loans. By reducing the costs related to small- scale loans, such arrangements enable formal lenders to make cheap loans available to smallholder farmers. The intent is that these loans will enable farmers to make investments and production decisions that would not be profitable at the high interest rates charged by informal lenders, but that become profitable at lower interest rates.

Foreign donors have shown great interest in microfinance. As a result, many microfinance schemes have had easy access to additional funds and been able to expand their lending. This has meant that loan recipients who face temporary or longterm problems in repaying their loans could, in many cases, bridge old loans by taking new ones. In other cases, because of the social pressure associated with repaying the loans, loan recipients have settled the amounts they owed by selling some of their property (see, for example, Copestake et al., 2001), by taking informal loans, or by cutting down on basic consumption needs (see, for example, Dattasharma et al., 2016). Thus, the high repayment rates that have characterised many microcredit schemes cannot, in themselves, be seen as indicators of how successful such schemes will be in the longer term, as long- term problems may be masked by short- term increases in available funds or by short- term measures taken by individual borrowers. In addition, in recent years, many microcredit institutions have increasingly shifted from group lending towards individual lending. For instance, in 2001, Grameen Bank moved to a "Grameen II'scheme for individual loans. Such institutions have, therefore, become increasingly similar to the older small- scale credit schemes and presumably risk facing the same problems as their older counterparts.

Given the adverse selection issues that have troubled smallscale formal credit schemes in the past, there should be some attempt to target those farmers who are most likely to use the invested funds successfully. If this is not done, repayment rates are likely to decline in the longer term. Findings from randomised experiments indicate that borrowers selected by microcredit schemes use the funds more successfully than borrowers selected at random (see, for example, Tedeschi, 2008), which can be seen as a minimum requirement for successful microfinance. However, this finding does not tell us whether formal lenders are as successful in selecting borrowers as informal lenders are. Indeed, the low profitability in many micro-finance institutions suggests that they may not be (Cull et al., 2007; Schäfer et al., 2010). The conventional view (Boucher and Guirkinger, 2007; Islam et al., 2015) is that formal lending displaces informal lending by making cheaper credit available to farmers who could have borrowed informally in any case. The remaining market for informal lending could then be explained either by the greater flexibility with which unregulated lenders operate, and/or by additional 
credit needs on the side of borrowers who also borrow formally (Pal, 2002; Hartarska and Nadolnyak, 2007; Barslund and Tarp, 2008; Mallick, 2012; Islam et al., 2015). However, an alternative and more problematic outcome could be that there is adverse selection in formal lending, with the result that formal lending reaches farmers who cannot borrow from informal lenders because they are seen as worse credit risks. While this is not a static issue - a prospective lender could be a poor credit risk because of local discrimination that constrains his/her access to key markets, and this could potentially be addressed through other policies (see, for example, Guérin et al., 2015) - as long as those other policies are not put in place, lending to such borrowers could put the long- term viability of the formal microcredit scheme at risk.

If the formal credit is not sufficiently large to achieve this outcome, the farmer will perceive a credit constraint, in that he would prefer to borrow more at the formal rate, and will face a shadow price of working capital that is higher than the formal interest rate. Thus, the farmer will wish to borrow additional funds informally and would be willing, if necessary, to pay a higher interest rate for these additional funds. The perception of being credit constrained is found across farmers in Bangladesh (Khandker and Koolwal, 2016), and so as an assumption is relevant here.

Assuming that there is also a market for informal credit in the area, informal lenders will be willing to lend to the farmer, provided that their expected profit from doing so is at least as great as that expected from lending the money to other borrowers. The informal lender' $\mathrm{s}$ iso- expected profit curve with respect to the size of the loan will be convex: it declines initially with the size of the loan because of the fixed costs associated with gathering information on the borrower, but it increases with further increases in loan size because of the increased risk of default associated with larger loans.

This means that an individual farmer will face an upwardsloping supply curve of informal credit, specific to that particular farmer, and determined by the informal lenders'perception of him/her. Bell (1990) shows that, depending on how competitive the informal market is, there is likely to be a credit constraint in the informal market as well, such that the farmer cannot borrow additional funds above some credit ceiling xi.

In all four cases, cheap formal credit generates a welfare improvement for the farmer because his overall borrowing costs are reduced. However, it is only in case A that the farmer' $\mathrm{s}$ investment decision will be directly determined at the margin by the formal interest rate. In all the other cases, the farmer' s marginal investment decision will be determined by the relationship between his shadow price of working capital and the interest rate that informal lenders offer. Since this informal rate will vary from farmer to farmer, it means the farmer' s shadow price of capital and, hence, the related marginal investment decision will be determined by how the farmer is perceived as a credit risk by informal lenders.

If a farmer faces a constraint on formal credit, but nonetheless chooses not to borrow informally, this is because his shadow price of working capital is lower than the informal rate that he is offered. We should note that the informal rate offered to this farmer is determined by the informal lenders'expected profit from lending to him rather than to other farmers. Thus, if the farmer' $\mathrm{s}$ shadow price is higher than the average informal interest rate, this indicates that the farmer is perceived as a poor credit risk by informal lenders. He would be prepared to borrow at the informal interest rates offered to other farmers, but is not offered the latter because the informal lenders'expected profit from doing so is less than the expected profit from lending to other borrowers at that rate. In this case, the farmer does not borrow informally because informal lenders are reluctant to lend to him, and the formal lender has made a poor choice when lending to this borrower rather than to others.

On the other hand, if the farmer' $s$ shadow price of working capital is lower than the informal interest rates offered to other farmers, the farmer' $\mathrm{s}$ main reason for not borrowing informally is that the formal credit takes care of most of his working capital needs. In this case, the farmer could (presumably) borrow informally at rates comparable to those offered to other farmers, but chooses not to do so because it would not be profitable.

Thus, we can study the adverse selection issue in formal lending by looking at whether farmers who only borrow formally have higher or lower shadow prices of working capital (and, hence, are perceived as worse or better credit risks) than the farmers who also take informal loans. If farmers who only borrow formally have an average shadow price of credit which is lower than the average informal interest rate, this means that formal credit has displaced informal lending and that the formal borrowers'main reason for not borrowing informally is that their credit needs have been met by formal loans. On the other hand, if formal borrowers have an average shadow price of credit which is higher than the informal interest rate, this means that they are unable to borrow because they are worse than average credit risks.

In order to analyse these issues, we studied the shadow prices for working capital among shrimp farmers in a rural region in Bangladesh where formal and informal small- scale credit schemes coexist. Some farmers in the study only used small- scale formal loans, a few used only informal loans, and some used both types of loans. Investigating whether there are systematic differences in shadow prices between borrowers who use only formal loans and those who also (or only) use informal loans, indicates how successful formal schemes have been in identifying farmers who are good credit risks.

If there are indeed differences in behaviour between the two groups of farmers, one potential explanation might be that there are differences in the technologies that they use. 1 If this is the case, there might be different ways of looking at this from a policy perspective. On the one hand, it might be desirable for formal microlenders to target farmers who use the most appropriate technology (because they are most likely to use the funds successfully). On the other hand, it could also be argued that the formal microcredit schemes should target those farmers who use less appropriate technologies in order to provide them with funds that can enable them to upgrade to better technologies. Because differences in technology between 
the two groups can be interpreted in different ways, such differences need to be disentangled from the issue of shadow prices for credit, which is the focus of this study. Thus, we need to examine technological differences separately.

\section{SHADOW PRICES}

In order to estimate the shadow price of capital, we apply a shadow price approach originally developed by Lau and Yotopoulos (1971) for use in efficiency measurement. The basic assumption behind this approach is that firms optimise with respect to shadow prices rather than observed market prices. These shadow prices are normally interpreted as measuring allocative inefficiencies due to poor input choices. The approach also allows farmers to be technically inefficient, i.e. they may not all use the best possible technology. However, in a situation such as that studied here, where most or all farmers are constrained in their use of one or several inputs, farmers will in fact optimise with respect to shadow prices rather than market prices even when they are allocatively efficient. If one assumes that there are no inefficiencies other than those caused by the input constraints, the estimated shadow prices can then be seen as measuring the actual shadow prices facing the individual farmer, rather than as measuring how inefficient the farmers are in their input use.

We assume that, apart from credit markets, the environment for shrimp farmers in rural Bangladesh can be characterised by competitive markets. Output is assumed to be demand- driven, with the result that input prices and output can be considered as exogenous. This makes the cost function an appropriate behavioural function. In order to examine whether there are systematic differences in the technology farmers employ, we used an input- oriented measure of technical efficiency, defined as the ability to minimise the input use for producing a given output. The underlying production function can then be specified as:

$$
y=f(\varphi x ; \beta) \exp \{v\} ;
$$

where $y$ is the farmer's scalar output, $x$ is the input vector, $f$ $(\mathrm{x} ; \beta)$ is the deterministic part of the production function, $\beta$ is a vector of parameters in the production function, $\nu$ is a symmetrically distributed stochastic error term with mean zero and constant variance, and $0 \leq \phi \leq 1$ is a measure of technical efficiency that can cause the cost function to shift (Kumbhakar and Lovell, 2000).

Similarly, it was assumed that, for those households that rented out labour or leased out land, the marginal value of such labour or land in own production was the price paid for it (because, presumably, the household would have used more of the labour or land in its own production if it had been more profitable to do so). If these price- taking assumptions hold, farm production decisions will be based solely on the prices of the marginal unit of each input. Thus, although the farm household is likely to make consumption, work and production decisions jointly in practice, production decisions can nonetheless be analysed separately from the household's other decisions (Sadoulet and de Janvry, 1995).

with formal loans) or Category D (credit- constrained, and financing at least some working capital requirements with informal loans). The fact that even farmers who borrow informally are credit- constrained indicates (following the reasoning in Bell, 1990) that competition among informal lenders is limited.

If one looks at the interest paid by each borrower on the last taka2 of formal loans (the marginal factor cost for formal loans), the marginal cost of capital was, on average, 14.3 per cent, i.e. almost the same. On the other hand, for farmers who also used informal loans, the differences in interest rates between the two types of loans meant that the marginal rate of interest on the last taka borrowed was substantially higher than the average rate of interest paid. The average rate of interest paid by these farmers was 24 per cent, but the marginal rate of interest on the last taka borrowed was, on average, 35 per cent. 3

\section{CONCLUSION}

Inclusivity could be raised in areas where competition in informal lending remains limited. In such locations, formal lenders might consider lending directly to existing and new informal lenders; increasing the availability of funds in the informal credit markets would increase the competition among informal lenders. This would, indirectly, reduce the interest rates in the informal credit market offered to current and potential borrowers, reducing borrowing costs for those borrowers who already participate in the informal market, and opening the credit markets for potential borrowers who are poor credit risks at current interest rates but who would become acceptable credit risks at lower interest rates.

\section{REFERENCES}

[1] Adams, D. W. and von Pischke, J. D. (1992). Microenterprise credit programs: Déjà vu. World Development, 20, 1463-1470.

[2] Akerlof, G. A. (1970). The market for 'lemons' : Quality uncertainty and the market mechanism. Quarterly Journal of Economics, 84, 488500 .

[3] Andersson, C., Holmgren, E., MacGregor, J. and Stage, J. (2008) Giving credit to the micro lenders. Formal microlending, credit constraints and adverse selection: a case study. Environmental Economics Programme Discussion Paper 08-02, International Institute for Environment and Development.

[4] Andersson, C., Holmgren, E., MacGregor, J. and Stage, J. (2011). Formal microlending and adverse (or non- existent) selection: A case study of shrimp farmers in Bangladesh. Applied Economics, 43, 42034211 .

[5] Armend á riz, B. and Morduch, J. (2005). The Economics of Microfinance. Cambridge, MA: MIT Press.

[6] Balcombe, K., Fraser, I., Latruffe, L., Rahman, M. and Smith, L. (2008) An application of the DEA Double Bootstrap to examine sources of efficiency in Bangladesh rice farming. Applied Economics, 40, 19191925 .

[7] Barslund, M. and Tarp, F. (2008). Formal and informal rural credit in four provinces of Vietnam. Journal of Development Studies, 44, 485503 . 